\title{
Synthesis of Novel Type Terpolymer Poly(Eugenol-co-methylmethacrylate-co- hydroxyethylmethacrylate) Using Photopolymerization Method: Characterization and Investigation of Thermal Properties
}

\author{
Fehmi Saltan ${ }^{1 *}$ \\ ${ }^{1}$ Department of Chemistry, Science Faculty, Çankırı Karatekin University, Uluyazı, 18100, Çankırı, Turkey
}

Geliş / Received: 24/11/2020, Kabul / Accepted: 07/12/2020

\begin{abstract}
In this study, it has been demonstrated that Poly(Eugenol-co-methylmethacrylate-cohydroxyethylmethacrylate) terpolymers were successfully synthesized by using photopolymerization method. This synthesis was carried out in one step at ambient temperature, benzophenone and triethyl amine was used as the photoinitiator and hydrogen donor, respectively. Methyl methacrylate (MMA), 2-Hydroxyethyl methacrylate (HEMA) and Eugenol (Eg) were used as monomer in photopolymerization. Terpolymers are named as F-BAP1, F-BAP2, F-BAP3 and F-BAP4 according to the ratio of monomers used. Structural characterization and thermal properties of the synthesized terpolymers were carried out by FTIR (Fouriertransform infrared spectroscopy), ${ }^{1} \mathrm{H}-\mathrm{NMR}$ (Nuclear magnetic resonance spectroscopy), TG-DTG (Thermogravimetry-Differential Thermogravimetry) and DSC (Differential scanning calorimetry) methods. Characterization of molecular weight distributions were determined by viscometric method. SEM (Scanning electron microscope) was used for surface analysis. According to the data obtained from thermal analysis, two degradation steps are seen in thermograms of the terpolymers except FBAP-2. The maximum degradation temperature of F-BAP 2 is $422^{\circ} \mathrm{C}$, the first and second decomposition temperatures of F-BAP1, F-BAP2, FBAP3 are between $250-280^{\circ} \mathrm{C}$ and $421-427^{\circ} \mathrm{C}$, respectively.
\end{abstract}

Keywords: Terpolymers, Eugenol, HEMA, MMA, Thermal Properties

\section{Fotopolimerizasyon Metodunu Kullanarak Yeni Tip Poli (Öjenol-ko-metil metakrilat-ko- hidroksietilmetakrilat) Terpolimerinin Sentezlenmesi: Karakterizasyonu ve Termal Özelliklerinin İncelenmesi}

$\ddot{\mathbf{O z}}$

Bu çalışmada, Poly (Eugenol-ko-metilmetakrilat-ko-hidroksietilmetakrilat) terpolimerlerinin fotopolimerizasyon yöntemi kullanılarak başarıyla sentezlendiği gösterilmiştir. Bu sentez, ortam sıcaklığında bir aşamada gerçekleştirildi, sırasıyla foto başlatıcı ve hidrojen donör olarak benzofenon ve trietil amin kullanıldı. Fotopolimerizasyonda monomer olarak metil metakrilat (MMA), 2-Hidroksietil metakrilat (HEMA) ve Öjenol (Eg) kullanıldı. Terpolimerler kullanılan monomerlerin oranına göre F-BAP1, F-BAP2, F-BAP3 ve F-BAP4 olarak adlandırıldı. Sentezlenen terpolimerlerin yapısal karakterizasyonu ve termal özellikleri FTIR (Fourier-transform infrared spektroskopi), ${ }^{1} \mathrm{H}-\mathrm{NMR}$ (Nükleer manyetik rezonans spektroskopisi), TG-DTG (Termogravimetri-Diferansiyel Termogravimetri) ve DSC (Diferansiyel taramalı kalorimetri) yöntemleri ile gerçekleştirildi. Moleküler ağırlık dağılımları viskometrik yöntemle belirlendi. Yüzey analizi için SEM (Taramalı elektron mikroskobu) kullanıldı. Termal analizden elde edilen verilere göre terpolimerlerin termogramlarda FBAP-2 haricinde iki bozunma basamağı görülmektedir. F-BAP 2'nin maksimum bozunma sicaklığı 422 ${ }^{\circ} \mathrm{C}$, diğer terpolimerlerin birinci bozunma sıcaklığı $250-280{ }^{\circ} \mathrm{C}$ ve ikincisi $421-427{ }^{\circ} \mathrm{C}$ arasındadır.

Anahtar Kelimeler: Terpolimerler, Öjenol, HEMA, MMA, Termal Özellikler. 


\section{Introduction}

In the recent times, polymeric materials obtained from bio-renewable sources have attracted great attention because of the scarcity and high price of oil and growing environmental worries (Lligadas et al., 2013; Lu and Larock, 2009; Hernández et al., 2020). A wide variety of bio-renewable polymeric materials have been enhanced using bio-renewable resources such as sugars (Ilyas et al., 2018), pine resin derivatives (Xia et al., 2013), lignins (Gadhave et al., 2018), furan (Huang et al., 2020), vegetable oils (Zhang and Kessler, 2015) and polysaccharides (Bilal and Iqbal, 2020). One of the most abundant biorenewable materials are Essential oils (EOs) which are aromatic compounds obtained from plants. Studies from the past to the present show that Essential oils can be used in diferent fields such as food industries (Santos et al., 2017), cosmetics (Sarkic and Stappen, 2018), pharmaceutics (Maccelli et al., 2019). One of these important EOs is Eugenol which is a hydroxyphenyl propene. It is naturally found in some plant families such as Lamiaceae, Lauraceae, Myrtaceae, and Myristicaceae. Also, Eugenol is one of the major constituents of clove oil. Many scientific studies support that the it has positive effects on human health (Marchese et al., 2017; Bezerra et al., 2017). Compared with synthetic polymers, the natural polymers particularly fill the gaps that are needed in specific biomedical applications due to their good biological performance such as biodegradability, biocompatibility, abundance in nature, injectability, similarities to a cellular matrix and low- cost production

Although the biological activities such as Antibacterial (Bilgiçli et al., 2019), antifungal (Olea et al., 2019), antioxidan (Miranda et al., 2018) and anti-inflammatory (Mateen et al., 2019) of Eugenol and its derivatives have been demonstrated, the usage in areas requiring oxidation resistance (Magalhaes et al., 2019), termal and flame resistance (Zhang et al., 2017) or sensitivity to light (Choi et al., 2009) of these natural compounds like as eugenol has been limited because of their volatile and unstable characteristics. Copolymerization is a technique that has been used for a long time to improve the disadvantages of polymeric materials. In this study, 2-hydroxyethyl methacrylate (HEMA) and methyl methacrylate (MMA) monomers were used together with eugenol in copolymerization.

Poly(2-hydroxyethyl methacrylate) (PHEMA) and Poly(Methyl methacrylate) (PMMA) are widely used polymers. PMMA has been used in various fields such as optoelectronics (Day and Kar, 2019), optic fibers (Proulx et al., 2013), and biomaterials (Neuta et al., 2001) owing to its good mechanical properties and optical (high transparency and clarity). Whereas, PHEMA is most widely used hydrogel (Zhang et al., 2014), because of the water content is similar to living tissues (Mackova et al., 2017). Also, its hydrophilicity basically from the hydroxyl functional group makes it blood- and biocompatibility and develops resistance to decomposition (Bajpai and Mishra, 2007). In addition to all this, PHEMA has good mechanical properties, favorable refractive index value and high oxygen permeability. PHEMA could be copolymerized with MMA (Çekingen et al., 2012) to adapt the wettability and hydrophilicity of PMMA, which can then be used in special 
applications such as in biomedical fields (Vargün et al, 2010) and in solid-state pulsed dye lasers (Costela et al., 1995).

In this article, we have demonstrated the successful synthesis of a novel type terpolymer by the photopolymerization method using the combination HEMA, MMA and Eugenol monomers. This terpolymer, methylmethacrylate-co-

hydroxyethylmethacrylate) was synthesized for the first time in the literature. The preferred method is photopolymerization, and this technique also adds a unique value to the work. Because previous similar studies used more traditional radical polymerization methods or controlled polymerization techniques, which are also based on radical polymerization.

\section{Material and Methods}

\section{Instrumentation}

${ }^{1} \mathrm{H}-\mathrm{NMR}$ spectra were recorded on Varian AS-400 spectrometers in $\mathrm{CDCl}_{3}$ with $\mathrm{Si}\left(\mathrm{CH}_{3}\right)_{4}$ as internal standard, FT-IR spectra were recorded on a Perkin Elmer FTIR Spectrum One-B spectrometer. Differential scanning calorimetry (DSC) was performed on a Perkin Elmer Diamond DSC. Thermal gravimetric analysis (TGA) and differantial thermal gravimetric analysis (DTG) was performed on Perkin-Elmer Diamond TA/TGA with a heating rate of $10{ }^{\circ} \mathrm{C} / \mathrm{min}$ under nitrogen flow. Scanning Electron Microscope (SEM) was performed on Thermo Scientific Apreo S. Viscometric analysis was carried out at a constant temperature of $25{ }^{\circ} \mathrm{C}$ by Oswald viscometer. Chloroform was used as solvent. $\mathrm{K}$ and $\alpha$ constants of chloroform at $25{ }^{\circ} \mathrm{C}$ are $49.8 \times 10^{5}(100 \mathrm{ml} / \mathrm{g})$ and 0.69 , respectively.

\section{Materials}

Eugenol (Sigma Aldrich, reagent plus, \%99, USA), Methyl Methacrylate, MMA (Sigma Aldrich, stabilized \%99, USA), 2Hydroxyethyl Methacrylate, HEMA (Sigma Aldrich, $\geq 99 \%$, contains $\leq 50 \mathrm{ppm}$ monomethyl ether hydroquinone as inhibitör, USA), Benzophenon (Sigma Aldrich, reagent plus, \%99, USA), Triethylamine (Sigma Aldrich, $\geq \% 99$, USA), Methanol (TEKKİM, $\geq \% 99$, Turkey)

\section{Poly (Eugenol-co-Methylmethacrylate-co- Hydroxyethylmethacrylate) (Poly (Eg-co- MMA-co-HEMA)) Synthesis-General Procedure}

Methylmethacrylate (MMA), Eugenol (Eg) and 2-Hydroxyethyl methacrylate (HEMA) monomers are added into the phototube in the required proportions. Before the monomers are added to the reaction medium, it is passed through the purification process in the alumina column. Benzophenone (BP) is added as photoinitiator, up to $1 \mathrm{~mol} \%$ of the total monomer ratio in the medium. Triethylamine ( $\mathrm{Et}_{3} \mathrm{~N}$ must be dry) is added in a catalytic amount as the H-donor. Argon is introduced into the phototube to provide an inert atmosphere. The solution is mixed and allowed to polymerize in the photoreactor for the required time. At the end of the reaction, the viscous liquid is diluted in a certain ratio with the help of a suitable solvent (Methanol). The polymer solution is added to the cold ether with the help of a pasteur pipette drop by drop and solid polymers are obtained. Polymer solids are filtered using sintered funnel (Por 2). Three times washing with ether is carried out to remove unreacted monomers and other components. Providing minimal contact of polymer solids with the atmosphere, it is quickly left to dry for one 
day in a $40{ }^{\circ} \mathrm{C}$ vacuum oven $(\mathrm{Mv}(\mathrm{F}-$ Structural characterization and thermal BAP1 $=21200 ; \quad F-B A P 2=20000 ; \quad F-$ properties of the synthesized terpolymers BAP3=26000; F-BAP4=22000)).

The required data in the synthesis of Poly (Eg-co-MMA-co-HEMA), whose general procedure is given above, are given in table 1. In addition, the mechanism of photopolymerization and polymerization reaction are shown in Figure 1 and Figure 2, respectively. were carried out by FTIR (Fourier-transform infrared spectroscopy), ${ }^{1} \mathrm{H}-\mathrm{NMR}$ (Nuclear magnetic resonance spectroscopy), TG-DTG (Thermogravimetry-Differential

Thermogravimetry) and DSC (Differential scanning calorimetry) methods. Characterization of molecular weight distributions were determined by viscometric method. SEM (Scanning electron microscope) was used for surface analysis.

\section{Results}

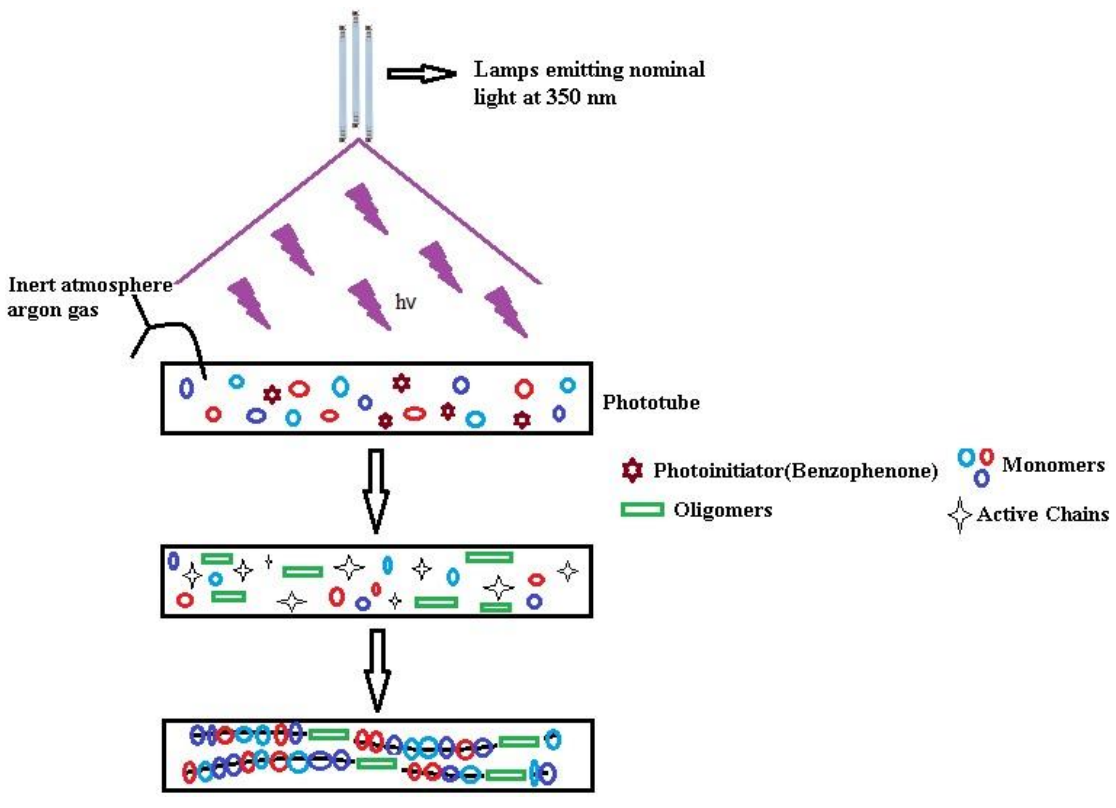

Figure 1. Synthesis of terpolymers by photopolymerization method.

Table 1. Initial mole ratios and yield percentages of poly (Eg-co-MMA-co-HEMA) synthesis

\begin{tabular}{|c|c|c|c|c|c|c|}
\hline $\begin{array}{c}\text { Polymer } \\
\text { Synthesis Code }\end{array}$ & Monomers & $\begin{array}{l}\text { Mole Ratios } \\
\text { (mole, ml) }\end{array}$ & $\begin{array}{l}\text { Photoinitiator } \\
\quad(\text { mole, g) }\end{array}$ & H-Donör & $\begin{array}{c}\text { Time } \\
\text { (hour) }\end{array}$ & Yield, \% \\
\hline \multirow{3}{*}{ F-BAP1 } & $\mathrm{Eg}$ & $\begin{array}{c}3 \\
(0,2814 \text { mole, } \\
4,35 \mathrm{ml}) \\
\end{array}$ & \multirow{3}{*}{$\begin{array}{c}4,69 \times 10^{-4} \mathrm{~mole}, \\
0,085 \mathrm{~g}\end{array}$} & \multirow{3}{*}{$\begin{array}{l}\text { catalytic } \\
\text { amount }(2 \\
\text { drops })\end{array}$} & \multirow{3}{*}{$\begin{array}{l}2 \\
4\end{array}$} & 38 \\
\hline & MMA & $\begin{array}{c}1 \\
(0,00938 \text { mole }, 1 \\
\mathrm{ml})\end{array}$ & & & & 49 \\
\hline & HEMA & $\begin{array}{c}1 \\
(0,00938 \mathrm{~mole} \\
1,14 \mathrm{ml})\end{array}$ & & & & 50 \\
\hline \multirow{3}{*}{ F-BAP2 } & $\mathrm{Eg}$ & $\begin{array}{c}1 \\
(0,00938 \mathrm{~mole} \\
1,45 \mathrm{ml}) \\
\end{array}$ & \multirow{3}{*}{$\begin{array}{c}4,69 \times 10^{-4} \text { mole } \\
0,085 \mathrm{~g}\end{array}$} & \multirow{3}{*}{$\begin{array}{c}\text { catalytic } \\
\text { amount }(2 \\
\text { drops) }\end{array}$} & \multirow[t]{3}{*}{2} & 57 \\
\hline & MMA & $\begin{array}{c}1 \\
(0,00938 \text { mole, } 1 \\
\mathrm{ml})\end{array}$ & & & & 59 \\
\hline & HEMA & $\begin{array}{c}3 \\
(0,2814 \text { mole, }\end{array}$ & & & & 62 \\
\hline
\end{tabular}




\begin{tabular}{|c|c|c|c|c|c|c|}
\hline & & $3,42 \mathrm{ml})$ & & & & \\
\hline \multirow{3}{*}{ F-BAP3 } & $\mathrm{Eg}$ & $\begin{array}{c}1 \\
(0,00938 \mathrm{~mole} \\
1,45 \mathrm{ml})\end{array}$ & \multirow{3}{*}{$\begin{array}{c}4,69 \times 10^{-4} \text { mole } \\
0,085 \mathrm{~g}\end{array}$} & \multirow{3}{*}{$\begin{array}{l}\text { catalytic } \\
\text { amount }(2 \\
\text { drops })\end{array}$} & \multirow{3}{*}{$\begin{array}{l}2 \\
4\end{array}$} & 61 \\
\hline & MMA & $\begin{array}{c}3 \\
(0,2814 \text { mole, } 3.0 \\
\mathrm{ml})\end{array}$ & & & & 66 \\
\hline & HEMA & $\begin{array}{c}1 \\
(0,00938 \mathrm{~mole} \\
1,14 \mathrm{ml}) \\
\end{array}$ & & & & 68 \\
\hline \multirow{3}{*}{ F-BAP4 } & $\mathrm{Eg}$ & $\begin{array}{c}1 \\
(0,00938 \text { mole } \\
1,45 \mathrm{ml})\end{array}$ & \multirow{3}{*}{$\begin{array}{c}2,81 \times 10^{-4} \mathrm{~mole}, \\
0,0512 \mathrm{~g}\end{array}$} & \multirow{3}{*}{$\begin{array}{c}\text { catalytic } \\
\text { amount }(2 \\
\text { drops) }\end{array}$} & 2 & 46 \\
\hline & MMA & $\begin{array}{c}1 \\
(0,00938 \text { mole, } 1 \\
\mathrm{ml})\end{array}$ & & & \multirow[t]{2}{*}{4} & 50 \\
\hline & HEMA & $\begin{array}{c}1 \\
(0,00938 \text { mole } \\
1,14 \mathrm{ml})\end{array}$ & & & & 51 \\
\hline
\end{tabular}<smiles>C=CCc1ccc(O)c(OC)c1</smiles>

Eg<smiles>C=C(C)C(=O)OC</smiles>

MMA<smiles>C=C(C)C(=O)OCCO</smiles>
$\underset{\text { Benzophenone }}{\longrightarrow}$ Iriethyl aminine<smiles>COc1cc(CC(CC(C)(C)OC)C(C)(C)C)ccc1O</smiles>

Poly(Eg-co-MMA-co-HEMA)

Figure 2. Synthesis of Poly (Eg-co-MMA-co-HEMA)

\section{FT-IR and H-NMR Analysis}

In Figure 3, FT-IR spectra of all the synthesized terpolymers are given comparatively. According to this figure, $-\mathrm{OH}$ peak on the aromatic ring has been observed in the frequency range of $3450-3480 \mathrm{~cm}^{-1}$ as expected. Aliphatic $\mathrm{C}-\mathrm{H}$ vibrations are between $2950-3050 \mathrm{~cm}^{-1}$. The vibration of the characteristic carboxyl peak found in HEMA and MMA monomers is at $1740 \mathrm{~cm}^{-1}$. The vibration frequency of the C-O-C ester bond has been observed in the expected range at $1150 \mathrm{~cm}^{-1}$. The shoulder peak of the aromatic compound on the Eugenol monomer was observed in the $1500 \mathrm{~cm}^{-1}$ band. FT-IR spectra support that synthesis is successful and the obtained FT-IR results are smilar to litarature (Al-Odayni et al., 2020).
Figure 4 showes the ${ }^{1} \mathrm{H}-\mathrm{NMR}$ of F-BAP1. According to this figure, the chemical shift value of eugenol in the aromatic region between 6.5 and $6.8 \mathrm{ppm}$ is seen. The proton peaks of $-\mathrm{OH}$ (on HEMA) and $-\mathrm{OH}$ (on Eugenol) are seen at 4.5 and $5.8 \mathrm{ppm}$, respectively. The characteristic $-\mathrm{OCH}_{3}$ methoxy peak is seen at $3.6 \mathrm{ppm}$. These ppm values are consistent with the results found in similar copolymerization studies with eugenol (Al-Odayni et al., 2020). O-CH $2^{-}$ and $-\mathrm{CH}_{2}-\mathrm{OH}$ proton peaks on the HEMA monomer were observed at 4.0 and $3.7 \mathrm{ppm}$, respectively. The chemical shift value of the proton belonging to $\mathrm{Ph}-\mathrm{CH}_{2}$, methylene attached to the aromatic ring was observed at 2 ppm. Other aliphatic $-\mathbf{C H}$ - peaks were seen between 1 and $1.5 \mathrm{ppm}$ as expected. All observed values are indicated on the figure. $\mathrm{CD}_{3} \mathrm{OH}$ (methanol) was used as solvent and 
solvent peaks of methanol were plotted on the figure. ${ }^{1} \mathrm{H}-\mathrm{NMRs}$ of other syntheses (FBAP2, F-BAP3, F-BAP4) are given in figure 5. The NMR views are similar because the products are the same. Only, mole ratios have been changed. Peak intensities vary because the composition ratios are different. Unlike other spectra, the methoxy peaks are separated in Figure 5-c. In the synthesis of FBAP2 in Figure 5-a, the intensity of the methoxy peak is decreased because the HEMA ratio is high. Due to the difficulty of the eugenol monomer to participate in the chain in radical polymerization, the peak intensities appear low in the general appearance of the spectra. However, when looking at the ${ }^{1} \mathrm{H}-\mathrm{NMR}$ Spectra of all syntheses, it can be said that the syntheses are successful.

\section{Optimization Work (\% yield-time)}

Figure 6 shows the effect of photopolymerization time on yield percentages of polymers. Increasing the duration according to the curves obtained increases the efficiency at a certain rate. The most impact was seen on the polymer with high eugenol ratio (F-BAP1). The reason for this is the low rate of eugenol attendance to the polymer chains. Therefore, the yield increase has become more evident with time for the F-BAP1. Looking at the other synthesizes,F-BAP2;F-BAP3, F-BAP4, the effect of time on yield was not very effective.

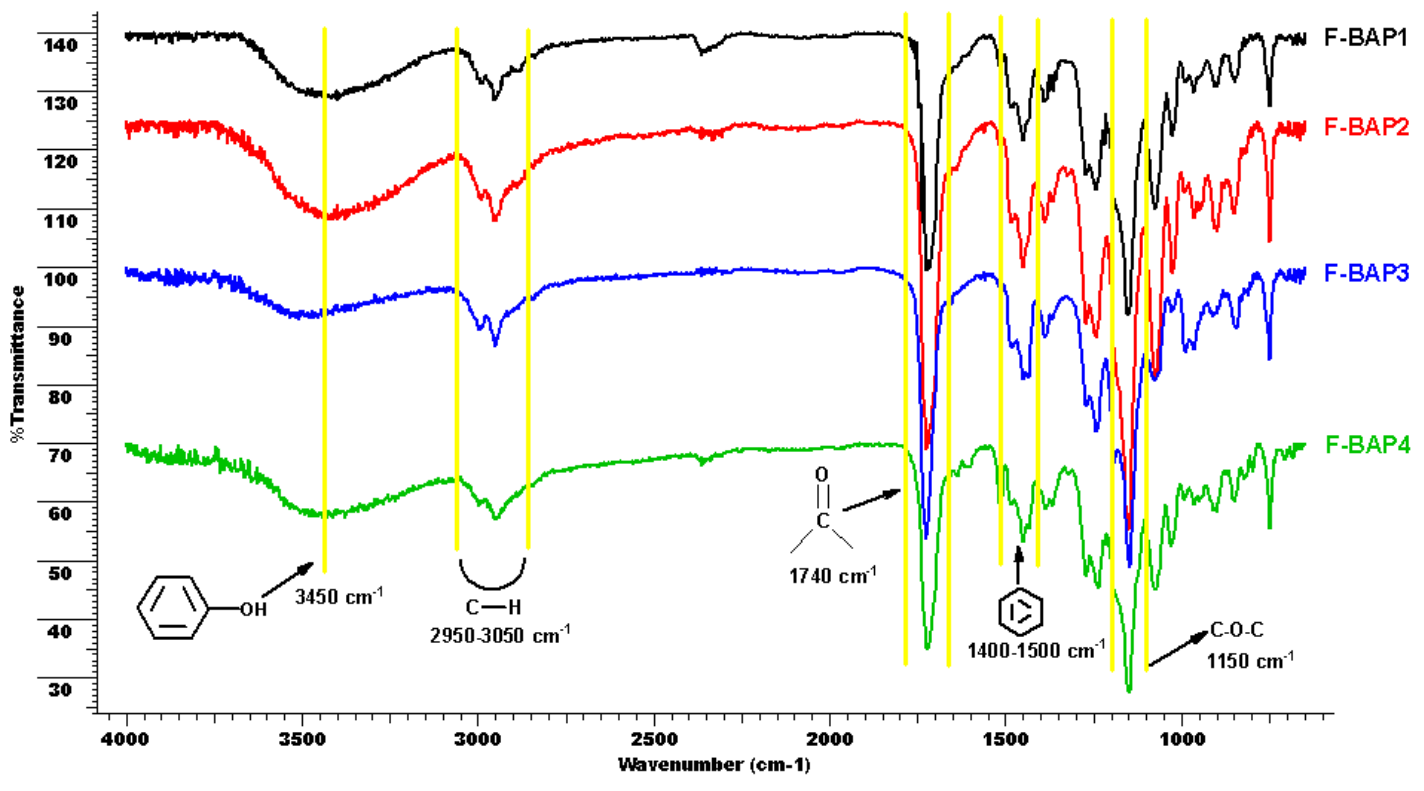

Figure 3. FT-IR spectra of F-BAP1, F-BAP2, F-BAP3 and F-BAP4 




Figure 4. ${ }^{1} \mathrm{H}-\mathrm{NMR}$ of F-BAP1

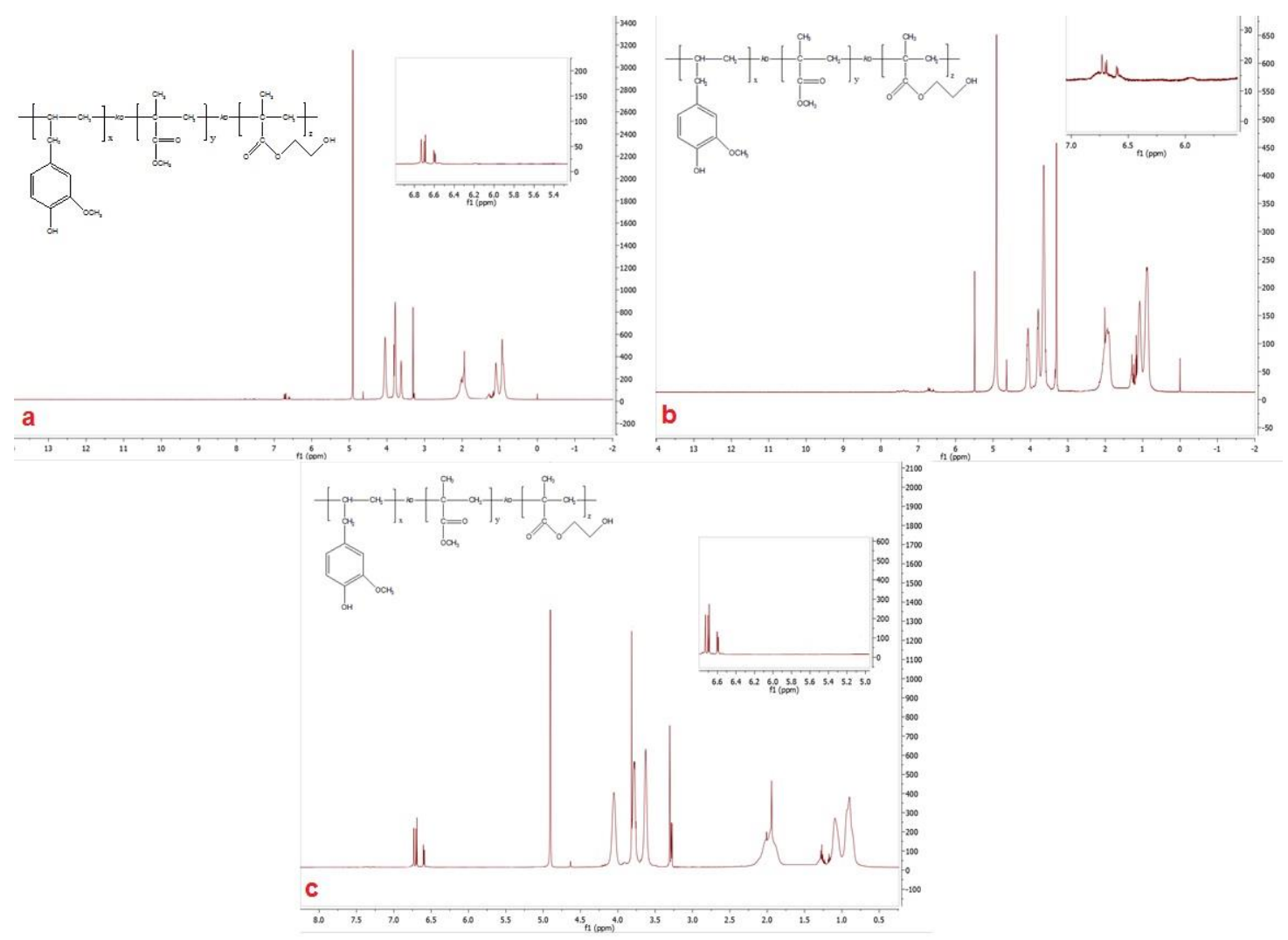

Figure 5. ${ }^{1} \mathrm{H}-\mathrm{NMR}$ of F-BAP2, F-BAP3 and F-BAP4 


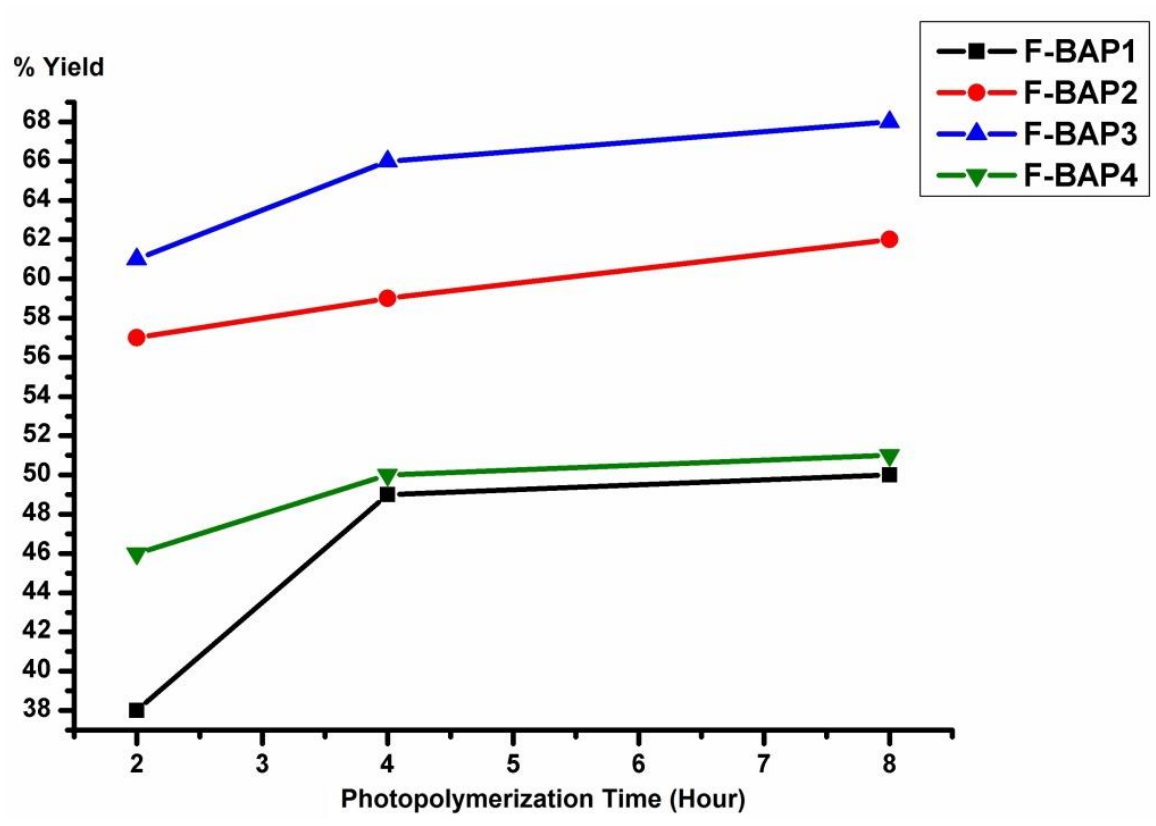

Figure 6. Optimization of F-BAP1, F-BAP2, F-BAP3 and F-BAP4

\section{Thermal Analyses}

Thermal degradation percentages of polymers were investigated by thermogravimetry. Maximum decomposition temperatures and degradation steps were determined by differential thermogravimetry (DTG). Figure 7 showes the TG and DTG curves of F-BAP1, F-BAP2, F-BAP3 and FBAP4. According to the data obtained from this figure, two degradation steps are seen in thermograms except FBAP-2. The reason why F-BAP 2 shows only one degradation step may be that in this polymerization a high percentage of moles of HEMA is added to the polymerization (table 1 shows the amount of monomers involved in the polymerization). According to the PHEMA literature data, it shows a single and main degradation step at approximately $350{ }^{\circ} \mathrm{C}$. It can be said that the thermogram of the terpolymer obtained in the synthesis of FBAP-2 has an appearance similar to the thermogram of PHEMA, which is its main skeleton, and its thermal stability has increased significantly. Its maximum decomposition temperature is $422{ }^{\circ} \mathrm{C}$. In the synthesis of FBAP1-2 and 3, 2 decay steps are seen and these steps are clearly determined on the figure 7. In this figure, two degradation steps are observed in PMMA. The presence of PMMA in FBAP-3 and other FBAP1-4 series, where PMMA is polymerized at a high molecular rate, may result in such a degradation. The first of the decomposition steps varies between 250-280 ${ }^{\circ} \mathrm{C}$ and the break here can be predicted as $\mathrm{CO}_{2}$ separation from the structure. The mass loss here is about $5-10 \%$. The break in the second and main step is between $421-427^{\circ} \mathrm{C}$ and is mainly due to the breakage of C-C bonds. In the literature, the temperature of the main decomposition step of PMMA is lower than the maximum decomposition temperatures of the polymers obtained here. It is possible that the high thermal decomposition temperatures of the terpolymers according to homopolymers may be due to the eugenol added to the structure. The main degradation step of terpolymers starts at about $340{ }^{\circ} \mathrm{C}$. This result is in agreement with the copolymer prepared with 
polyeugenol in the literatüre (Rojo et al., 2008).
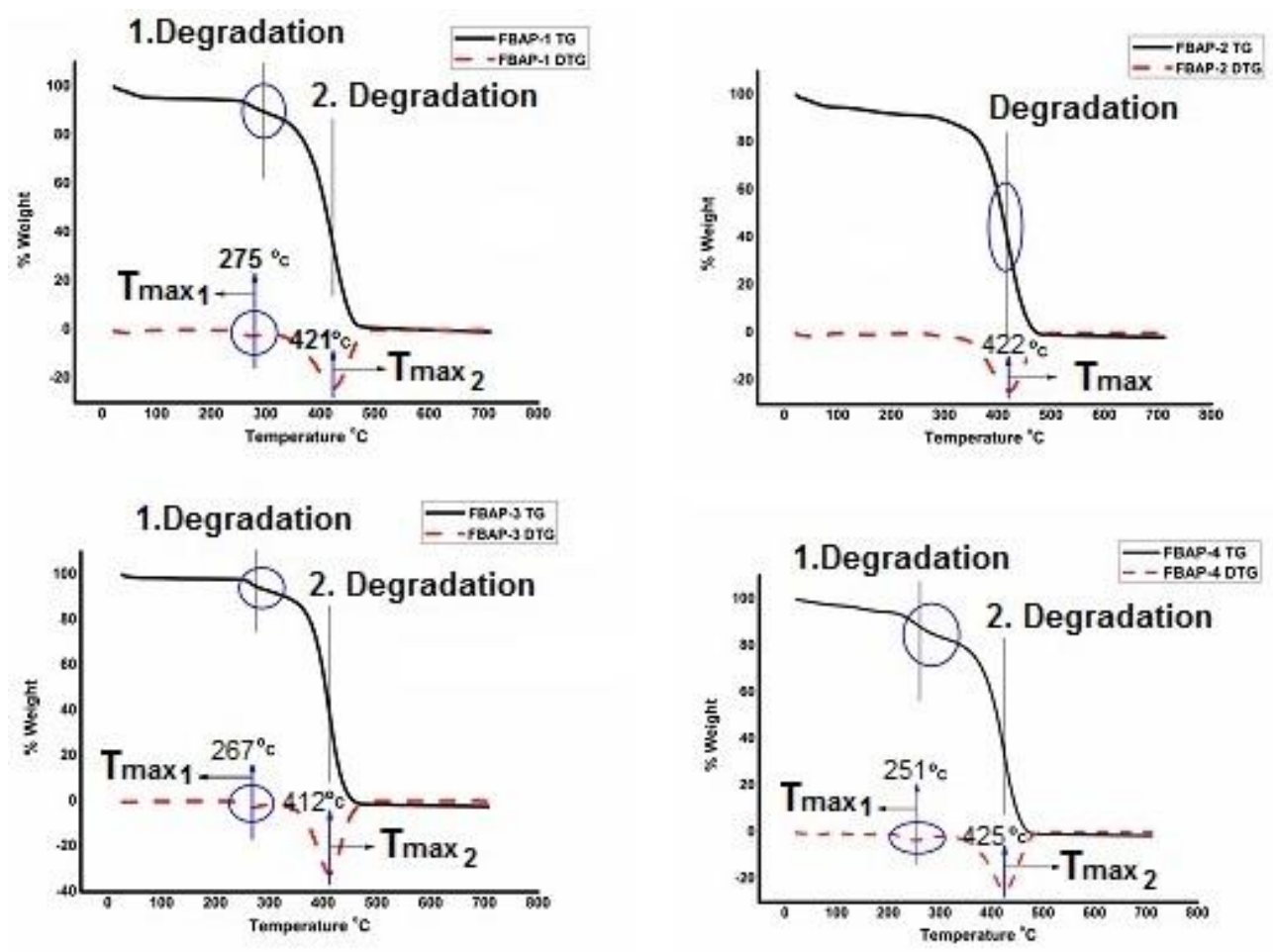

Figure 7. TG and DTG curves of F-BAP1, F-BAP2, F-BAP3 and F-BAP4

Figure 8 shows the DSC curves of $410-425^{\circ} \mathrm{C}$ refers to an endothermic reaction synthesized terpolymers (F-BAP1, F-BAP2, by "melting". In contrast, DSC curve of the F-BAP3 and F-BAP4). According to this F-BAP2 did not show first endothermic peak. figure, the DSC curves have been showed no This result may be due to the thermal shift of the baseline indicating "glass characteristic of HEMA in the polymer. transition". The first and second endothermic Similar DSC curves of PHEMA are seen in peaks observed at around $250-275{ }^{\circ} \mathrm{C}$ and the literatüre (Vargün and Usanmaz, 2010). 




Figure 8. DSC curves of F-BAP1, F-BAP2, F-BAP3 and F-BAP4

\section{SEM}

Figure 9 shows the SEM imaging of synthesized terpolymers. When the figure 9 has been investigated, it is seen that all images have different surface views. This is due to the fact that each polymer contains different ratios of monomers. When the surface morphology of the synthesis of FBAP1, where eugenol is found in a high proportion, a spherical appearance is seen. It is seen in the literature that similar SEM images were obtained in studies with Eugenol (Xu et al., 2019; Simoes et al., 2020). The image of F-BAP2 is similar to a sea sponge. In this synthesis (F-BAP2), the HEMA monomer is relatively high and the SEM images of PHEMA are generally similar to figure 9 (F-BAP2) (Çetin et al., 2011). SEM image of F-BAP3 which has high MMA monomer ratio has big spherical appearance. This image proves that the MMA ratio is high in the structure (Jiang et al., 2010). When all SEM images are evaluated together, it can be said that characteristic images of the monomers used are obtained. Each image showed a different surface character in response to varying mole ratios. 


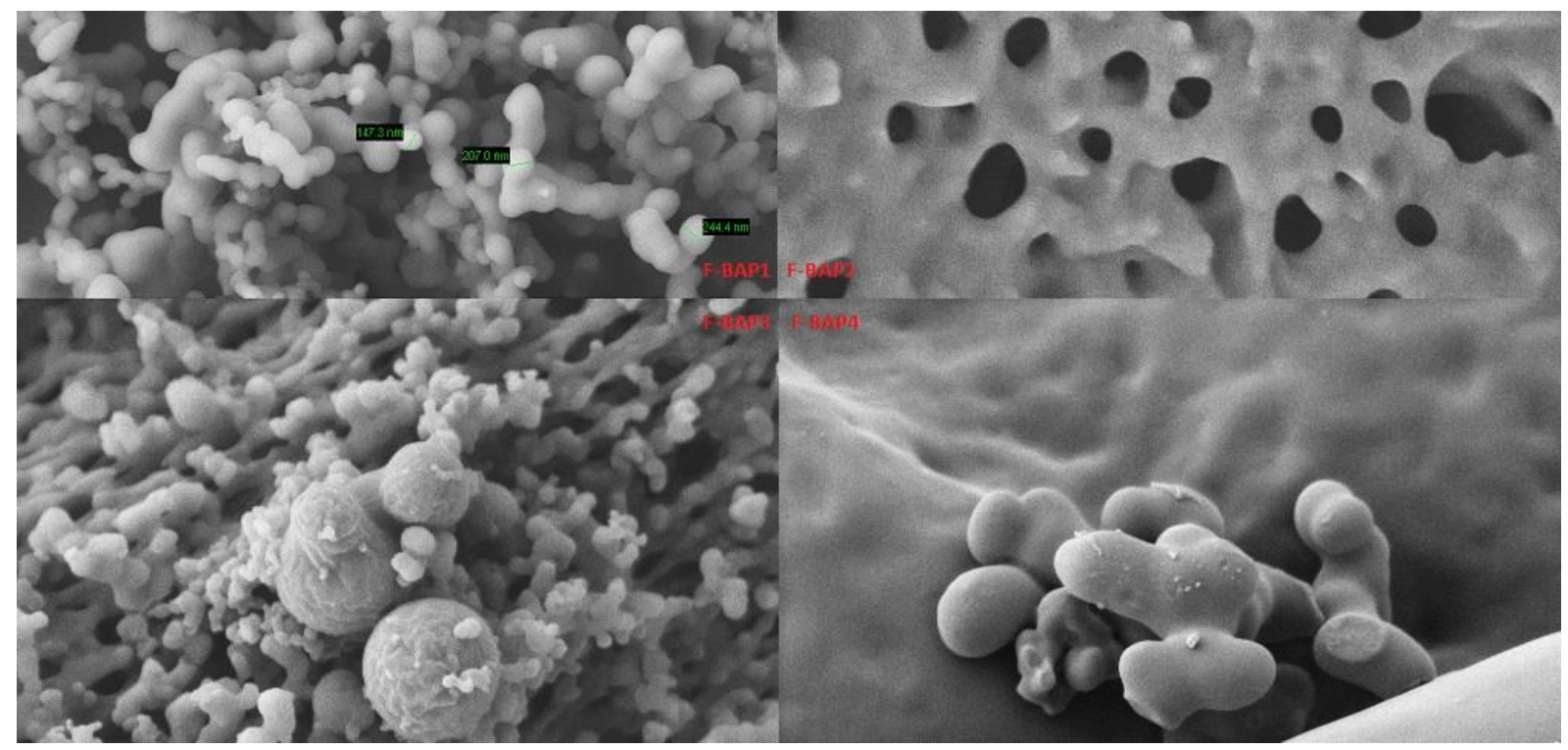

Figure 9. SEM images of F-BAP1, F-BAP2, F-BAP3 and F-BAP4

\section{Conclusion}

Poly(Eugenol-co-methylmethacrylate-cohydroxyethylmethacrylate) terpolymers were successfully synthesized by using photopolymerization method. According the obtained data from TG curves, two degradation steps are seen in thermograms except FBAP-2. The reason why F-BAP 2 shows only one degradation step may be that in this polymerization a high percentage of moles of HEMA is added to the polymerization. The main degradation step of terpolymers starts at about $340{ }^{\circ} \mathrm{C}$ and this degradation temperature is more higher than PHEMA and PMMA homopolymers. The reason of this result is eugenol in copolymers. Optimization studies show that the time parameter is not more effect on the polymerization yield. Yields of terpolymers has slightly increased after four hour. SEM images of the synthesized terpolymers were obtained similar to the images of PHEMA PMMA and Eugenol.

Acknowledge: This study was supported by Çankırı Karatekin University Scientific
Research Projects Coordination Unit with project number FF080120B01.

\section{References}

Al-Odayni, A. B., Saeed, W. S., Ahmed, A. Y. B. H., Alrahlah, A., Al-Kahtani, A., and Aouak, T. 2020. "New Monomer Based on Eugenol Methacrylate, Synthesis, Polymerization and Copolymerization with Methyl Methacrylate-Characterization and Thermal Properties", Polymers, 12, 160-188.

Bajpai, A. K., and Mishra, D. D. 2018. "Dynamics of blood proteins adsorption onto poly (2- hydroxyethyl methacrylate)- silica nanocomposites: Correlation with biocompatibility". Journal of Applied Polymer Science, 107(1), 541-553.

Bezerra, D. P., Militão, G. C. G., Morais, M. C. and Sousa, D. P. 2017. "The Dual Antioxidant/Prooxidant Effect of Eugenol and Its Action in Cancer Development and Treatment", Nutrients, 9, 1367.

Bilal, M., and Iqbal, H. M. N. 2019. "Marine Seaweed Polysaccharides-Based Engineered Cues for the Modern Biomedical Sector", Marine Drugs, 18, 7. 
Bilgiçli, H. G., Kestane, A., Taslimi, P., Karabay, O., Damoni, A. B., Zengin, M., and Gulçin, İ. 2019. "Novel eugenol bearing oxypropanolamines:

Synthesis, characterization, antibacterial, antidiabetic, and anticholinergic potentials", Bioorganic Chemistry, 88, 10293.

Choi, M. J., Soottitantawat, A., Nuchuchua, O., Min, S. G., and Ruktanonchai, U. 2009. "Physical and light oxidative properties of eugenol encapsulated by molecular inclusion and emulsion-diffusion Method". Food Research International, 42(1), 148-156.

Costela, A., Florido, F., Garcia-Moreno, I., Duchowicz, R., Amat-Guerri, F., Figuera, J. M., and Sastre, R. 1995. "Solid-state dye lasers based on copolymers of 2hydroxyethyl methacrylate and methyl methacrylate doped with rhodamine 6G", Applied Physics B, 60, 383-389.

Çekingen, S. K., Saltan, F., Yildirim, Y., and Akat, H. 2012. "A novel HEMA-derived monomer and copolymers containing sidechain thiophene units: Synthesis, characterization and thermal degradation kinetics", Thermochimica Acta, 546, 87-93.

Çetin, D., Sera Kahraman, A., and Gümüsderelioglu, M. 2011. "Novel Scaffolds Based on Poly(2-hydroxyethyl methacrylate) Superporous Hydrogels for Bone Tissue Engineering" Journal of Biomaterials Science, 22, 1157-1178.

Dey, S., and Kar, A. K. 2019. " Enhanced photoluminescence through Forster resonance energy transfer in PolypyrrolePMMA blends for application in optoelectronic devices", Materials Science in Semiconductor Processing, 103, 104644.

Gadhave, R. V., Mahanwar, P. A., and Gadekar, P. T. 2018. "Lignin-Polyurethane Based Biodegradable Foam", Open Journal of Polymer Chemistry, 8, 1-10.
Hernández, E., Mosiewicki, M. A., and Marcovich, N. E. 2020. "Bio-Based Polymers Obtained from Modified Fatty Acids and Soybean Oil with Tailorable Physical and Mechanical Performance", European Journal Lipid Science and Technology, 122, 2000182.

Huang, W., Hu, X., Zhai, J., Zhu, N., and Guo, K. 2020. "Biorenewable furancontaining polyamides", Materials Today Sustainability, 10, 100049.

Ilyas, R. A., Sapuan, S. M. Ishak, M. R. Zainudin, E. S., and Atikah, M. S. N. 2018. "Characterization of Sugar Palm Nanocellulose and Its Potential for Reinforcement with a Starch-Based Composite", Sugar Palm Biofibers, Biopolymers, \& Biocomposites, Taylor and Francis, England, 189-219.

Jiang, W., Sun, Y., Xu, Y., Peng, C., Gong, X., and Zhang, Z. 2010. "Shear-thickening behavior of polymethylmethacrylate particles suspensions in glycerine-water mixtures", Rheol Acta, 49, 1157-1163.

Lligadas, G., Ronda, J. C., Galia, M., and Ca'diz, V. 2013. "Renewable polymeric materials from vegetable oils: a perspective", Materials Today, 16(9), 337-343.

Lu, Y., and Larock R. C. 2009. "Novel Polymeric Materials from Vegetable Oils and Vinyl Monomers: Preparation, Properties, and Applications", ChemSusChem, 2, 136147.

Maccelli, A., Vitanza, L., Imbriano, A., Fraschetti, C., Filippi, A., Goldoni, P., Maurizi, L., Ammendolia, M. G., Crestoni, M. E., Fornarini, S., Menghini, L., Carafa, M., Marianecci, C., Longhi, C., and Rinaldi, F. 2019. "Satureja montana L. Essential Oils: Chemical Profiles/Phytochemical Screening, Antimicrobial Activity and O/WNanoEmulsion Formulations", Pharmaceutics, $12,7$. 
Mackova, H., Plichta, Z, Hlidkova, H., Sedlacek, O., Konefal, R., Sadakbayeva, Z., Smrckova, M. D., Horák, D., and Kubinova, S. 2017. "Reductively degradable poly(2hydroxyethyl methacrylate) hydrogels with oriented porosity for tissue engineering applications", ACS Applied Materials and Interfaces, 9(12), 10544-10553.

Magalhães, C. B., Casquilho, N. V., Machado, M. N., Riva, D. R., Travassos, L. H., Cardoso, J. H. L., Fortunato, R. S., Faffe, D. S., and Zin, W. A. 2019. "The antiinflammatory and anti-oxidative actions of eugenol improve lipopolysaccharide-induced lung injury", Respiratory Physiology \& Neurobiology, 259, 30-36.

Marchese, A., Barbieri, R., Coppo, E., Orhan, I. E., Daglia, M., Nabavi, S. F., Izadi, M., Abdollahi, M., Nabavi, S. M., and Ajami, M. 2017. "Antimicrobial activity of eugenol and essential oils containing eugenol: A mechanistic viewpoint", Critical Reviews in Microbiology, 43(6), 668-689.

Mateen, S., Rehman, M. T., Shahzad, S., Naeem, S. S., Faizy, A. F., Khand, A. Q., Khan, M. S., Husain, F. M., and Moin, S. 2019. "Anti-oxidant and anti-inflammatory effects of cinnamaldehyde and Eugenol on mononuclear cells of rheumatoid arthritis patients", European Journal of Pharmacology, 852, 14-24.

Miranda, K. A. G., Rivas, B. L., Rivera, M. A. P., Sanfuentes, E. A., and Farfal, C. P. 2018. "Antioxidant and antifungal effects of eugenol incorporated in bionanocomposites of poly(3-hydroxybutyrate)-thermoplastic starch", LWT-Food Science and Technology, 98, 260-267.

Neuta, D., Belta, H., Stokroos, I., Horn, J. R., Mei, H. C., and Busscher, H. J. 2001. "Biomaterial-associated infection of gentamicin-loaded PMMA beads in orthopaedic revision surgery", Journal of Antimicrobial Chemotherapy, 47, 885-891.
Olea, A. F., Bravo, A., Martínez, R., Thomas, M., Sedan, C., Espinoza, L., Zambrano, E., Carvajal, D., Moreno, E. S., and Carrasco, H. 2019. "Antifungal Activity of Eugenol Derivatives against Botrytis Cinerea", Molecules, 24, 1239.

Proulx, F. T., Beaulieu, L., Archambault, L., and Beddar, S. 2013. "On the nature of the light produced within PMMA optical light guides in scintillation fiber-optic dosimetry", Physics in Medicine \& Biology, $58,2073$.

Rojo, L., Barcenilla, J, M., Vazquez, B., Gonzalez, R., and Roman, J. S. 2008. "Intrinsically Antibacterial Materials Based on Polymeric Derivatives of Eugenol for Biomedical Applications",

Biomacromolecules, 9, 2530-2535.

Santos, R. R., Andrade, M., Melo, N. R., and Silva, A S. 2017. "Use of essential oils in active food packaging: Recent advances and future trends", Trends in Food Science \& Technology, 61, 132-140.

Sarkic, A., and Stappen, I. 2018. "Essential Oils and Their Single Compounds in Cosmetics-A Critical Review", Cosmetics, 5, 11.

Simoes, M.G., Coimbra, P., Carreira, A. S., Figueiredo, M. M., Gil, M. H., and Simoes, P. N. 2020. "Eugenol-loaded microspheres incorporated into textile substrates", Cellulose, 27, 4109-4121.

Vargün, E., Sankir, M., Aran, B., Sankir, N. D., and Usanmaz, A. 2010. "Nanotechnology and Membrane Synthesis and Characterization of 2-Hydroxyethyl Methacrylate (HEMA) and Methyl Methacrylate (MMA) Copolymer Used as Biomaterial", Journal of Macromolecular Science, Part A, 47(3), 235-240.

Vargün, E., and Usanmaz, A. 2010. "Degradation of Poly(2-hydroxyethyl 
methacrylate) Obtained by Radiation in

Aqueous Solution", Journal of Macromolecular Science, Part A: Pure and Applied Chemistr, 47, 882-891.

Xia, Y., Quirino, R. L., and Larock, R. C. 2013. "Bio-based Thermosetting Polymers from Vegetable Oils", Journal of Renewable. Materials, 1(1), 3-27.

Xu, H., Zhang, D., and Li, J. 2019. "Antibacterial Nanoparticles with Universal Adhesion Function Based on Dopamine and Eugenol", Journal of Bioresources and Bioproducts, 4(3), 177-182.

Zhang, C., and Kessler, M. R. 2015. "Biobased Polyurethane Foam Made from Compatible Blends of Vegetable-Oil-based Polyol and Petroleum-based Polyol", ACS Sustainable Chemistry and Engineering, 3, 743-749.

Zhang, L., Zheng, G. J., Guo, Y. T., Zhou, L., Du, J., and He, H. 2014. "Preparation of novel biodegradable pHEMA hydrogel for a tissue engineering scaffold by microwaveassisted polymerization", Asian Pacific Journal of Tropical Medicine, 7(2), 136-140.

Zhang, X., Akram, R., Zhang, S., Ma, H., $\mathrm{Wu}, \mathrm{Z}$., and $\mathrm{Wu}, \mathrm{D} .2017$. "Hexa(eugenol) cyclotriphosphazene modified bismaleimide resins with unique thermal stability and flame retardancy", Reactive and Functional Polymers, 113, 77-87. 